\title{
PENGARUH ROA, TINGKAT INFLASI DAN NILAI TUKAR RUPIAH TERHADAP HARGA SAHAM
}

\author{
Selvi Yona Sari ${ }^{1)}$, Neni Sri wahyuni Nengsi ${ }^{2)}$, Desi Permata Sari ${ }^{3)}$ and Anisa Tunaswara ${ }^{4)}$ \\ ${ }^{1}$ Fakultas Ekonomi, Universitas Putra Indonesia YPTK \\ Selvi.yona@gmail.com
}

\begin{abstract}
His study aims to analyze the effect of Return On Assets, Inflation Rate and Rupiah Exchange Rate on the share price of banking companies on the Indonesia Stock Exchange. Based on the results of the research processed for the variables Return on Assets, Inflation Rate and Rupiah Exchange Rate on Stock Prices shows the simultaneous and significant influence. This is shown in the results of hypothesis testing with $F$ count. 36.99996> F table 3.06. With a significance of $0.000000<0.05$. The Return On Assets variable is partially negative and insignificant on the Stock Price. This is shown in the results of hypothesis testing with the number $t$ count $<t$ table that is $0.577606<1.65566$ with a significance value of $0.5647>0.05$. Variable Inflation Levels on Stock Prices show a positive and significant influence. This is shown in the results of hypothesis testing with a calculated number of 14.42283> t table 1.65566 with a significance value of 0.0000 $<0.05$. While the Rupiah Exchange Rate partially has a negative but significant effect on the Stock Price. This is shown in the results of hypothesis testing with the number $t-12.45095<t$ table 1.65566 with a significance value of $0.0000<0.05$.
\end{abstract}

Keywords: Return On Assets (ROA); Inflation Rate; Exchange Rate; Stock Price.

\begin{abstract}
Abstrak
Penelitian ini bertujuan untuk menganalisis pengaruh Return On Assets, Tingkat Inflasi dan Nilai Tukar Rupiah terhadap Harga saham perusahaan Perbankan di Bursa Efek Indonesia. Berdasarkan hasil penelitian yang diolah untuk variabel Return On Assets, Tingkat Inflasi dan Nilai Tukar Rupiah terhadap Harga Saham memperlihatkan adanya pengaruh secara simultan dan signifikan. Hal tersebut ditunjukkan pada hasil uji hipotesis dengan angka $F$ hitung. 36,99996 $>F$ tabel 3,06. Dengan signifikansi sebesar $0.000000<$ 0,05. Variabel Return On Assets secara parsial berpengaruh negatif dan tidak signifikan terhadap Harga Saham. Hal tersebut ditunjukkan pada hasil uji hipotesis dengan angka $t$ hitung $<t$ tabel yaitu $0.577606<$ 1,65566 dengan nilai signifikansi sebesar $0.5647>0,05$. Variabel Tingkat Inflasi terhadap Harga Saham memperlihatkan adanya pengaruh positif dan signifikan. Hal tersebut ditunjukkan pada hasil uji hipotesis dengan angka hitung $14.42283>t$ table 1,65566 dengan nilai signifikansi sebesar 0,0000 $<0,05$. Sedangkan Nilai Tukar Rupiah secara parsial berpengaruh negatif tetapi signifikan terhadap Harga Saham. Hal tersebut ditunjukkan pada hasil uji hipotesis dengan angka thitung $-12.45095<t_{\text {tabel }} 1,65566$ dengan nilai signifikansi sebesar $0.0000<0,05$.
\end{abstract}

Kata Kunci : Return On Assets (ROA); Tingkat Inflasi ; Nilai Tukar Rupiah; Harga Saham

\section{PENDAHULUAN}

\section{Latar Belakang}

Krisis keuangan selalu didahului oleh fluktuasi dan ketidakstabilan makro ekonomi yang menyebabkan depresiasi mata uang domestik secara siknifikan, menyulut tingginya tingkat bunga dan inflasi serta ketidakstabilan makro ekonomi.

Peristiwa tersebut untuk perbankan merupakan peristiwa yang tidak terduga, yang menimbulkan kepanikan para pelaku bisnis dalam melakukan kerjasama. Untuk itu, sektor perbankan perlu menumbuhkan kembali citra perbankan dengan meningkatkan kepercayaan kepada masyarakat maupun pelaku bisnis. Meskipun tekanan terhadap kondisi perekonomian nasional biasanya dinilai kurang kondusif bagi dunia usaha dan perbankan, namun sampai saat ini tidak sedikit perbankan yang tetap mampu mengelola risiko pada seluruh kegiatan usahanya berdasarkan prinsip kehati- hatian (prudent banking). Selain itu, 
sistem pengendalian risiko secara umum tetap kuat karena perbankan akan terus meningkatkan penyesuaian pengelolaan manajemen risiko pada semua aktivitas fungsionalnya sehingga setiap risiko yang ada dapat diidentifikasi, diukur, dipantau dan dikendalikan dengan baik. Hal ini penting untuk diperhatikan, sebagai salah satu faktor yang mendukung sistem perbankan yang kuat, berkualitas, tetap berlandaskan pada prinsip terpercaya dan dapat memenuhi ke-tentuan terwujudnya bank yang sehat.

Harga saham terbentuk karena adanya permintaan (demand) dan penawaran (supply) suatu saham. Apabila kinerja perusahaan baik, tentu keuntungan investor dalam pembagian dividen akan bertambah dan harga sahamnya akan menjadi semakin tinggi. Investor melakukan penilaian terhadap harga saham dengan membandingkan nilai intrinsik perusahaan dengan harga saham. Sehingga dapat diketahui apakah harga saham overvalued atau undervalued.

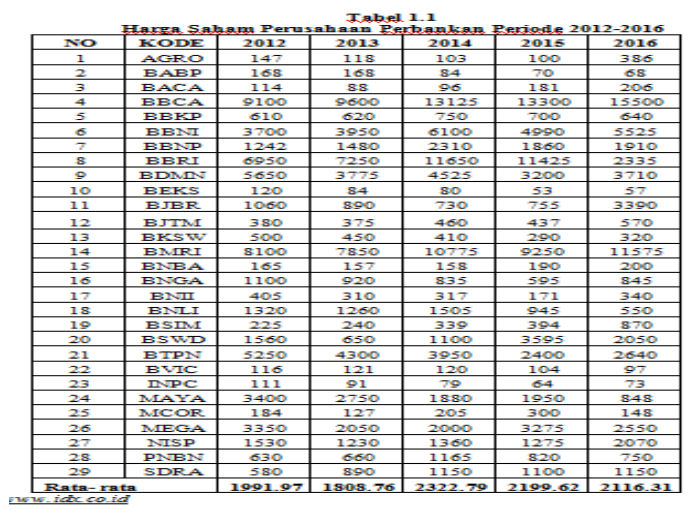

Dari tabel 1.1 diatas dapat dilihat dari beberapa perusahaan yang terdaftar di BEI periode 2012-2016 menunjukkan bahwa harga saham berfluktuasi dari tahun ke tahun yang dapat dilihat dari nilai rata-rata pertahunnya, dimana rata-rata pada tahun 2012 sebesar 1.991,97, tahun 2013 sebesar 1.808,76, tahun 2014 sebesar 2.322,79, tahun 2015 sebesar 2.199,62 dan tahun 2016 sebesar 2.116,31. Berfluktuasinya harga saham tersebut dipengaruhi oleh variabel Return On Assets
(ROA), tingkat inflasi dan nilai tukar rupiah. Dengan adanya penelitian ini, para investor yang akan berinvestasi dapat memperoleh informasi untuk membantu menentukan apakah harus membeli, menahan atau menjual investasi tersebut. Pemegang saham juga tertarik pada informasi yang memungkinkan mereka untuk menilai kemampuan perusahaan untuk membayar dividen.

\section{Landasar Teori}

\section{Return On Assets (ROA)}

Menurut (Hery, 2015) Return On Assets (ROA) merupakan rasio yang menunjukkan beberapa besar konstribusi aset dalam menciptakan laba bersih. Return On Assest (ROA) adalah salah satu bentuk dari rasio profitabilitas untuk mengukur kemampuan perusahaan dalam menghasilkan laba dengan menggunakan total aktiva yang ada dan setelah biaya-biaya modal (biaya yang digunakan mendanai aktiva) dikeluarkan dari analisis. Dengan kata lain, rasio ini digunakan untuk mengukur seberapa jumlah laba bersih yang akan dihasilkan dari setiap rupiah dana yang tertanam dalam total aset. Rasio ini menunjukkan kemampuan perusahaan dengan menggunakan seluruh aktiva yang dimiliki untuk menghasilkan laba setelah pajak.

\section{Tingkat Inflasi}

Inflasi merupakan suatu kejadian yang menggambarkan situasi dan kondisi di mana harga barang mengalami kenaikan dan nilai mata uang mengalami pelemahan. Jika kondisi ini terjadi secara terus menerus, akan berdampak pada semakin buruknya kondisi ekonomi secara menyeluruh serta terjadi guncangan pada tatanan stabilitas politik suatu negara. Inflasi merupakan realitas sekarang dari kemungkinan berlanjut di masa datang dan terulang kembali sepanjang waktu, maka penting bagi investor dan pengambil kebijakan moneter mencoba untuk mencari aset apakah yang dapat digunakan untuk menghindari kerugian yang diakibatkan.

\section{Nilai Tukar Rupiah}

Menurut (Nopirin, 2012) nilai merupakan harga di dalam pertukaran dan dalam pertukaran antara dua macam mata uang yang 
berbeda, akan terdapat perbandingan nilai atau harga antara kedua mata uang tersebut. Perbandingan nilai inilah yang disebut kurs exchange rate. Nilai tukar merupakan harga atau nilai tukar mata uang lokal terhadap mata uang asing. Para pelaku dalam pasar internasional amat peduli terhadap penentuan nilai tukar valuta asing (valas), karena nilai tukar valas akan mempengaruhi biaya dan manfaat "bermain"dalam perdagangan barang, jasa dan surat berharga. Nilai tukar merupakan harga suatu mata uang relatif terhadap mata uang Negara lain

\section{Harga Saham}

Secara sederhana yang disebut dengan indeks harga adalah suatu angka yang digunakan untuk membandingkan suatu peristiwa dibandingkan dengan peristiwa lainnya. Angka indeks atau sering disebut dengan indeks saja, pada dasarnya merupakan suatu angka yang dibuat sedemikian rupa sehingga dapat dipergunakan untuk melakukan perbandingan antara kegiatan yang sama dalam dua waktu yang berbeda. Indeks harga saham adalah suatu angka yang digunakan untuk membandingkan perubahan harga saham dari waktu ke waktu, apakah suatu harga saham mengalami penurunan atau kenaikan dibandingkan dengan suatu waktu tertentu.Indeks harga saham sebagai indikator perdagangan saham, yang disusun dengan satu formula tertentu yang berlangsung di bursa efek.

\section{METODOLOGI PENELITIAN}

\section{Analisis Data Deskriptif}

Menurut (Ghozali, 2016) statistik deskriptif memberikan gambaran atau deskripsi pada suatu perusahaan yang dapat dilihat melalui nilai rata-rata (mean), standar deviasi, varian, maksimum, minimum, sum range, kurtosis dan skewness.

\section{Uji Asumsi Klasik}

\section{Uji Normalitas}

Uji normalitas dilakukan untuk menguji apakah dalam sebuah model regresi, variabel independen dan dependen atau keduanya mempunyai distribusi normal atau tidak.

\section{Uji Multikolinearitas}

Uji ini digunakan untuk menguji apakah dalam sebuah model regresi ditemukan adanya korelasi antar variabel independen.

\section{Uji Heterokedastisitas}

Menurut(Lupiyoadi, 2015), suatu model pengujian seperti regresi linear berganda, maka data harus terbebas dari gejala heteroskedastisitas.

\section{Pemilihan Model Estimasi Regresi Data Panel}

\section{Uji Chow}

Uji Chow digunakan untuk menentukan model analisis data panel yang akan digunakan. Uji Chow digunakan untuk memilih antara model Fixed Effect atau Model Common Effect yang sebaiknya dipakai.

\section{$\mathrm{H} 0$ : Common Effect \\ $\mathrm{Ha}$ : Fixed Effect}

\section{Uji Hausman}

Uji Hausman digunakan untuk mengetahui model yang sebaiknya dipakai, yaitu Fixed Effect Model (FEM) atau Random Effect Model (REM). Hipotesis dalam uji hausman sebagai berikut :

H0 : Random Effect Model

Ha : Fixed Effect Model

\section{Analisis Regresi Liniear Berganda}

Menurut data pengamatan biasanya tidak hanya disebabkan oleh satu variabel saja melainkan beberapa atau bahkan banyak variabel. Secara umum data hasil pengamatan $\mathrm{Y}$ dipengaruhi oleh variabel X1, X2, $\mathrm{X} 3, \ldots . \mathrm{XN}$, sehingga rumus umum dari regresi linear berganda ini adalah :

$H S=a+b_{1} R O A_{i t}+b_{2} T I_{i t}+b_{3} N T R_{i t}+e$

Keterangan :
$\begin{array}{ll}\text { HS } & \text { Harga Saham } \\ \mathrm{a} & =\text { Koefisien Konstanta } \\ \mathrm{b} & =\text { Koefisien Regresi } \\ \text { ROA } & =\text { Return On Assets } \\ \text { TI } & =\text { Tingkat Inflasi }\end{array}$




\section{NTR = Nilai Tukar Rupiah e $\quad=$ Standar Error}

Pengujian Hipotesis

\section{Uji Signifikan Parsial (Uji t)}

Menurut Priyatno (2013) Uji t digunakan untuk mengetahui apakah $\mathrm{X}$ berpengaruh secara signifikan terhadap Y.

\section{Uji Simultan (Uji f)}

Menurut (Ghozali, 2014) uji $\mathrm{F}$ adalah bagian uji statistik yang digunakan untuk menguji suatu kelayakan model regresi dimana variabel independen berpengaruh terhadap dependen.

\section{Koefisien Determinasi $\left(\mathbf{R}^{2}\right)$}

Menurut(Ghozali, 2013). Uji koefisien determinasi $\left(\mathrm{R}^{2}\right)$ intinya mengukur tingkat ketepatan dari hasil regresi linear berganda yaitu persentase sumbangan (goodness of fit) dari variabel bebas terhadap variabel terikat .

\section{HASIL DAN PEMBAHASAN}

\section{Analisis Data Deskriptif}

Tabel 4.5

\begin{tabular}{|c|c|c|c|c|c|}
\multicolumn{5}{c|}{ Hasil Uji Statistik Deskriptif } \\
\hline HS & ROA & TI & NTR \\
\hline Mean & 2087.890 & 0.020443 & 5.516000 & 8.606800 \\
\hline Median & 755.0000 & 0.017000 & 6.380000 & 6.634000 \\
\hline Maximum & 15500.00 & 0.133500 & 6.970000 & 26.05000 \\
\hline Minimum & 53.00000 & 0.000500 & 3.530000 & -2.600000 \\
\hline Std. Dev. & 3126.488 & 0.016324 & 1.357443 & 9.850575 \\
\hline Skewness & 2.272739 & 3.222707 & -0.425273 & 0.766093 \\
\hline Kurtosis & 7.784559 & 20.40430 & 1.408616 & 2.374078 \\
\hline Jarque-Bera & 263.1350 & 2081.071 & 19.67127 & 16.55036 \\
\hline Probability & 0.000000 & 0.000000 & 0.000054 & 0.000255 \\
\hline Sum & 302744.0 & 2.964200 & 799.8200 & 1247.986 \\
\hline Sum Sq. Dev. & $1.41 \mathrm{E}+09$ & 0.038373 & 265.3419 & 13972.87 \\
\hline Observations & 145 & 145 & 145 & 145 \\
\hline
\end{tabular}

Sumber: Hasil output Eviews 8, diolah

Berdasarkan tabel diatas menjelaskan secara deskriptif variabel-variabel dalam penelitian ini. Variabel Return On Assets (ROA) memiliki nilai rata-rata sebesar 0,020443 dengan standar deviasi 0,016324. Nilai Maksimum sebesar 0,133500 dan nilai minimum sebesar 0,000500. Variabel Tingkat Inflasi memiliki nilai rata-rata sebesar 5,516000 dengan standar deviasi 1,357443. Nilai Maksimum sebesar 6,970000 dan nilai minimum sebesar 3,530000. Variabel Nilai Tukar Rupiah memiliki nilai rata-rata sebesar
8,606800 dengan standar deviasi 9,850575. Nilai Maksimum sebesar 26,05000 dan nilai minimum sebesar -2,600000. Variabel Harga Saham memiliki nilai rata-rata sebesar 2.087,890 dengan standar deviasi 3126,488. Nilai Maksimum 15500,00 sebesar dan nilai minimum sebesar 53,00000

\section{Uji Asumsi Klasik Uji Normalitas}

Tabel 4.7

Hasil Uji Normalitas Jarque-Bers Test

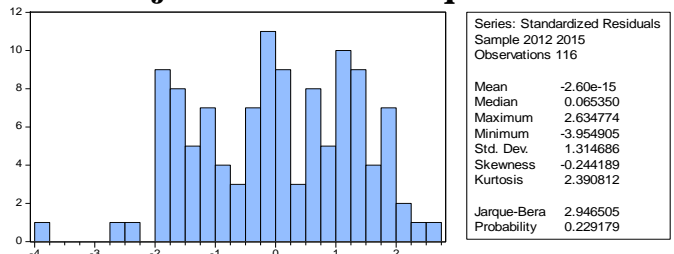

Sumber : Data Diolah, 2018

Berdasarkan tabel diatas diketahui bahwa nilai probabilitas Jarque-Bera adalah sebesar 0,229179 lebih besar dari taraf nyata yang digunakan $(\alpha=5 \%)$ sehingga dapat disimpulkan bahwa data yang digunakan berdistribusi normal yang artinya asumsi klasik tentang kenormalan telah dipenuhi.

\section{Uji Multikolonieritas}

\section{Tabel 4.7 \\ Hasil Uji Multikolinearitas}

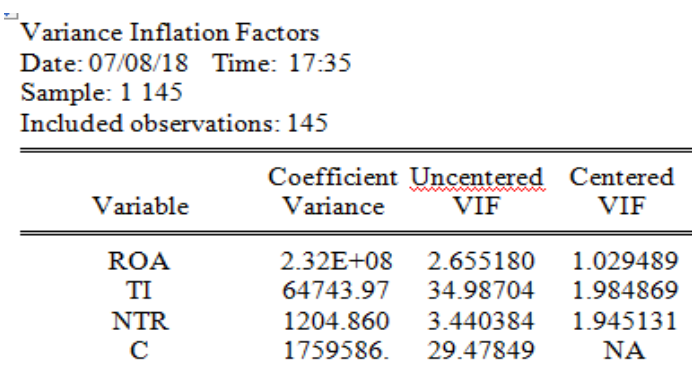

Sumber: Hasil output Eviews 8, diolah

Berdasarkan tabel diatas nilai VIF dilihat pada bagian Centered VIF. Nilai VIF untuk variabel Return On Assets (ROA) 1,029489 artinya variabel ini tidak terjadi multikolinearitas karena nilai VIF < 10, untuk variabel Tingkat Inflasi 1,984869 artinya variabel ini tidak terjadi multikolinearitas karena nilai VIF $<10$, untuk variabel Nilai Tukar Rupiah sebesar 1,945131 artinya variabel ini tidak terjadi multikolinearitas karena nilai VIF $<10$. 
Sehingga kesimpulannya bahwa semua variabel independen Return On Assets (ROA), Tingkat Inflasi dan Nilai Tukar Rupiah terbebas dari asumsi klasik multikolonieritas karena nilai VIF < dari 10.

\section{Uji Heteroskedastisitas}

Tabel 4.8 Hasil Uji Heteroskedastisitas

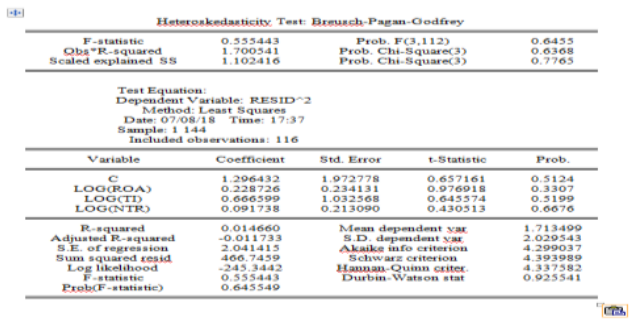

diolah

Sumber: Hasil output Eviews 8,

Berdasarkan tabel diatas dapat diketahui bahwa nilai Prob.Obs $* R$-squared $>0,05$ yaitu sebesar 0,6368 . Artinya bahwa tidak terdapat masalah heteroskedastisitas pada penelitian ini.

\section{Hasil Pemilihan Model Regresi Data Panel}

\section{Uji Chow}

Tabel 4.9

Hasil Uji Chow

\begin{tabular}{cccc}
$\begin{array}{c}\text { Redundant Fixed Effects Tests } \\
\text { Equation: Untitled } \\
\text { Test cross-section fixed effects }\end{array}$ & & \\
\hline Effects Test & Statistic & d.f. & Prob. \\
\hline $\begin{array}{c}\text { Cross-section F } \\
\text { Cross-section Chi-square }\end{array}$ & 34.978998 & $(28,113)$ & 0.0000 \\
& 328.969550 & 28 & 0.0000 \\
\hline
\end{tabular}

Sumber: Hasil output Eviews 8, diolah

Berdasarkan tabel diatas dapat diketahui bahwa nilai probabilitas cross-section ChiSquare adalah sebesar $0,0000<0,05$ artinya $\mathrm{H}_{1}$ diterima, Jadi kesimpulannya model yang digunakan adalah Fixed Effect Model (FEM). Maka selanjutnya akan dilakukan uji Hausman apakah akan menggunakan Fixed Effect Model (FEM) atau Random Effect Model (REM

\section{Uji Hausman}

Tabel 4.10

Hasil Uji Hausman

\begin{tabular}{|c|c|c|c|}
\hline Test Summary & Chi-Sq. Statistic & Chi-Sq. d.f. & Prob. \\
\hline Cross-section random & 0.000000 & 3 & 1.0000 \\
\hline
\end{tabular}

Sumber: Hasil output Eviews 8, diolah

Berdasarkan tabel diatas dapat diketahui bahwa nilai probabilitas cross-section random adalah sebesar $1,0000>0,05$ artinya $\mathrm{H}_{1}$ ditolak, Jadi kesimpulannya model yang digunakan adalah Random Effect Model (REM).

\section{Uji Regresi Linear Berganda}

Tabel 4.11

Hasil Regresi Liniear Berganda

\begin{tabular}{lrrrr}
\hline \multicolumn{1}{c}{ Variable } & Coefficient & Std. Error & t-Statistic & Prob. \\
\hline ROA & 2407.805 & 4168.596 & 0.577606 & 0.5647 \\
TI & 126.1293 & 8.745117 & 14.42283 & 0.0000 \\
NTR & -24.93307 & 2.002503 & -12.45095 & 0.0000 \\
C & 1557.532 & 86.40091 & 18.02680 & 0.0000 \\
\hline \multicolumn{5}{c}{ Effects Specification } \\
\hline Cross-section fixed (dummy variables) \\
\hline R-squared & 0.910317 & Mean dependent var & 2087.890 \\
Adjusted R-squared & 0.885714 & S.D. dependent var & 3126.488 \\
S.E. of regression & 1056.946 & Akaike info criterion & 16.95619 \\
Sum squared resid & $1.26 E+08$ & Sehwarz eriterion & 17.61312 \\
Log likelihood & -1197.324 & Hannan=Quinn criter & 17.22312 \\
F-statistio & 36.99996 & Durbin-Watson stat & 2.092000 \\
Prob(F-statistic) & 0.000000 & & \\
\hline
\end{tabular}

Sumber: Hasil output Eviews 8, diolah

Berdasarkan perhitungan diperoleh nilai koefisien regresi Return On Assets $\left(\mathrm{X}_{1}\right)$ sebesar 2.407,805, nilai koefisien regresi Tingkat Inflasi $\left(\mathrm{X}_{2}\right)$ sebesar 126,1293 , nilai koefisien regresi Nilai Tukar Rupiah $\left(\mathrm{X}_{3}\right)$ sebesar -24,93307, dan nilai konstan sebesar 1557,532. Berdasarkan angka tersebut maka dapat disusun persamaan garis regresi sebagai berikut :

HS $=1.557,532+2.407,805 \mathrm{ROA}+126,1293$ TI+ 24,93307 NTR + e

Interpretasi atau penjelasan dari persamaan regresi diatas adalah sebagai berikut :

1. Nilai konstansta $(\alpha)$ adalah $1.557,532$ artinya jika Return On Assets $\left(\mathrm{X}_{1}\right)$, Tingkat Inflasi $\left(\mathrm{X}_{2}\right)$, Nilai Tukar Rupiah $\left(\mathrm{X}_{3}\right)$, nilainya adalah 0 maka Harga Saham (Y) nilainya adalah meningkat sebesar 1.557,532 .

2. Nilai koefisien regresi variabel Return On Assets $\left(\mathrm{X}_{1}\right)$ bernilai positif sebesar 2.407,805 artinya jika Return On Assets meningkat sebesar satu (1) 
satuan, maka Harga Saham naik sebesar 2.407,805 dengan asumsi variabel independen lain bernilai 0 atau diabaikan.

3. Nilai koefisien regresi variabel Tingkat Inflasi $\left(\mathrm{X}_{2}\right)$ bernilai positif sebesar 126,1293 artinya jika Tingkat Inflasi meningkat sebesar satu (1) satuan, maka Harga Saham naik sebesar 126,1293 dengan asumsi variabel independen lain bernilai 0 atau diabaikan.

4. Nilai koefisien regresi variabel Nilai Tukar Rupiah $\left(\mathrm{X}_{3}\right)$ bernilai negatif sebesar -24,93307 artinya jika Nilai Tukar Rupiah meningkat sebesar satu (1) satuan, maka Harga Saham akan menurun sebesar 24,93307 dengan asumsi variabel independen lain bernilai 0 atau diabaikan.

\section{Uji Hipotesis}

\section{Uji Signifikansi Parsial (Uji t)}

Uji statistik $\mathrm{t}$ digunakan untuk menunjukkan seberapa jauh pengaruh satu variabel independen terhadap variabel dependen dengan menganggap variabel independen lainnya konstan (Ghozali, 2016). Pengujian ini dilakukan dengan membandingkan nilai probabilitas atau p-value (sig-t) dengan taraf signifikansi 0,05 . Jika nilai p-value lebih kecil dari 0,05 maka $\mathrm{H}_{0}$ diterima, dan sebaliknya jika p-value lebih besar dari 0,05 maka $\mathrm{H}_{0}$ ditolak.

Pada penelitian ini merupakan uji dua arah dengan taraf signifikansi $(\alpha) 0,05$ dan df $(n=145, k=3, d f=n-k$, sehingga $d f=145-3=142)$. Maka diperoleh hasil untuk $t$ tabel sebesar 1,65566 (Tabel t). Berdasarkan tabel 4.11 dapat diperoleh hasil sebagai berikut :

1. Pengujian variabel ROA $\left(X_{1}\right)$ terhadap Harga Saham (Y)

a. Berdasarkan $t_{\text {hitung dan }} t_{\text {tabel }}$

Pada hasil output Eviews 8.0 dapat dilihat $\mathrm{t}$ hitung untuk variabel ROA $\left(\mathrm{X}_{1}\right)$ sebesar 0,577606. Nilai $\mathrm{t}$ hitung $>\mathrm{t}$ tabel yaitu $0,577606<1,65566$ artinya Return On Assets secara parsial berpengaruh negatif terhadap Harga Saham pada perusahaan perbankan yang terdaftar di BEI.

b. Berdasarkan angka signifikansi
Pada hasil output eviews 8.0 dapat diketahui bahwa signifikansi untuk variabel Return On Assets $\left(\mathrm{X}_{1}\right)$ sebesar 0,5647 > 0,05 sehingga hipotesis pertama ditolak. Hipotesis pertama adalah diduga Return On Assets tidak berpengaruh signifikan terhadap Harga Saham pada perusahaan perbankan yang terdaftar di BEI. Dapat disimpulkan bahwa $\mathrm{H}_{0}$ diterima dan $\mathrm{H}_{\mathrm{a}}$ ditolak.

2. Pengujian variabel Tingkat Inflasi $\left(X_{2}\right)$ terhadap Harga Saham (Y)

a. Berdasarkan $t_{\text {hitung dan }} \mathrm{t}_{\text {tabel }}$

Pada hasil output eviews 8.0 dapat dilihat $\mathrm{t}$ hitung untuk variabel Tingkat Inflasi $\left(\mathrm{X}_{2}\right)$ sebesar 14,42283 . Nilai $t$ hitung $>\mathrm{t}$ tabel yaitu $14,42283>1,65566$ artinya Tingkat Inflasi secara parsial berpengaruh positif terhadap Harga Saham pada perusahaan perbankan yang terdaftar di BEI.

b. Berdasarkan angka signifikansi

Pada hasil output Eviews 8.0 dapat diketahui bahwa signifikansi untuk variabel Tingkat Inflasi $\left(\mathrm{X}_{2}\right)$ sebesar $0,0000<0,05$ sehingga hipotesis kedua diterima. Hipotesis kedua adalah diduga Tingkat Inflasi berpengaruh signifikan terhadap Harga Saham pada perusahaan perbankan yang terdaftar di BEI. Dapat disimpulkan bahwa $\mathrm{H}_{0}$ ditolak dan $\mathrm{H}_{\mathrm{a}}$ diterima.

3. Pengujian variabel Nilai Tukar Rupiah $\left(X_{3}\right)$ terhadap Harga Saham (Y)

a. Berdasarkan $t_{\text {hitung dan }} t_{\text {tabel }}$

Pada hasil output Eviews 8.0 dapat dilihat $\mathrm{t}$ hitung untuk variabel Nilai Tukar Rupiah $\left(\mathrm{X}_{3}\right)$ sebesar -12.45095 . Nilai $\mathrm{t}_{\text {hitung }}<\mathrm{t}$ tabel yaitu $-12.45095<1,65566$ artinya Nilai Tukar Rupiah secara parsial tidak berpengaruh negatif terhadap Harga Saham pada perusahaan perbankan yang terdaftar di BEI.

b. Berdasarkan angka signifikansi

Pada hasil output Eviews 8.0 dapat diketahui bahwa signifikansi untuk variabel Nilai Tukar Rupiah $\left(\mathrm{X}_{3}\right)$ sebesar $0,0000<0,05$ sehingga hipotesis ketiga diterima. Hipotesis ketiga adalah diduga Nilai Tukar Rupiah berpengaruh signifikan terhadap Harga Saham. Artinya, Nilai Tukar Rupiah berpengaruh signifikan terhadap Harga Saham pada perusahaan perbankan yang terdaftar di BEI. $\mathrm{H}_{0}$ ditolak dan $\mathrm{H}_{\mathrm{a}}$ diterima. 


\section{Uji Signifikansi Secara Simultan (Uji F)}

(Ghozali, 2016) Uji F menunjukkan apakah semua variabel independen mempunyai pengaruh secara bersama-sama terhadap variabel dependen. Hasil uji $\mathrm{F}$ dapat dilihat sebagai berikut Pada penelitian ini dengan nilai $(\mathrm{n}=145, \mathrm{k}=3) \quad \mathrm{df}_{1} \quad\left(\mathrm{df}_{1}=3-1 \quad\right.$ sehingga $\left.\mathrm{df}_{1}=3-1=2\right) \quad$ dan $\quad \mathrm{df}_{2} \quad\left(\mathrm{df}_{2}=\mathrm{n}-\mathrm{k}, \quad\right.$ sehingga $\mathrm{df}_{2}=145-3=142$ ). Maka diperoleh hasil untuk $F_{\text {tabel }}$ sebesar 3,06 (Tabel F). Berdasarkan tabel 4.11 dapat diperoleh hasil sebagai berikut :

Pengujian variabel Return On Assets $\left(\mathrm{X}_{1}\right)$, Tingkat Inflasi $\left(\mathrm{X}_{2}\right)$, dan Nilai Tukar Rupiah $\left(\mathrm{X}_{3}\right)$, terhadap Harga Saham (Y).

1. Berdasarkan $F_{\text {hitung }}$ dan $F_{\text {tabel }}$

Pada hasil output Eviews 8.0 dapat dilihat $\mathrm{F}$ hitung sebesar 36,99996. Nilai $\mathrm{F}$ hitung $>\mathrm{F}$ tabel yaitu $36.99996>3,06$ sehingga terdapat pengaruh. Jadi dapat disimpulkan bahwa Return On Assets, Tingkat Inflasi dan Nilai Tukar Rupiah secara simultan berpengaruh positif terhadap Harga Saham pada perusahaan perbankan yang terdaftar di BEI.

2. Berdasarkan angka signifikansi

Pada hasil output Eviews 8.0 dapat diketahui bahwa signifikansi sebesar $0,000000<0,05$ sehingga hipotesis keempat diterima. Hipotesis keempat adalah diduga Return On Assets, Tingkat Inflasi dan Nilai Tukar Rupiah secara bersama-sama berpengaruh signifikan terhadap Harga Saham. Artinya, Return On Assets, Tingkat Inflasi dan Nilai Tukar Rupiah secara simultan berpengaruh signifikan terhadap Harga Saham pada perusahaan perbankan yang terdaftar di BEI. Dapat disimpulkan bahwa $\mathrm{H}_{0}$ ditolak dan $\mathrm{H}_{\mathrm{a}}$ diterima.

\section{Uji Koefisien Determinasi $\left(\mathbf{R}^{2}\right)$}

\section{Tabel 4.12}

\section{Uji Koefisien Determinasi}

$\begin{array}{cccc}\text { R-squared } & 0.910317 & \text { Mean dependent var } & 2087.890 \\ \text { Adjusted R-squared } & 0.885714 & \text { S.D. dependent var } & 3126.488\end{array}$

Dari tabel 4.12, dapat dilihat bahwa angka koefisien korelasi (R) sebesar 0,910317. Hal ini berarti hubungan antar variabel independen dengan variabel dependen sebesar 91,03\% .
Dari angka tersebut dapat diambil kesimpulan bahwa hubungan antara variabel independen dengan variabel dependen sangat kuat. Besarnya Adjusted R-Square $\left(\mathrm{R}^{2}\right)$ sebesar 0,885714 . Hasil perhitungan statistik ini berarti bahwa kemampuan variabel independen dalam menerangkan variasinya perubahan variabel dependen sebesar $88,57 \%$, sedangkan sisanya sebesar $11,43 \%(100 \%$ $88,57 \%$ ) diterangkan oleh faktor-faktor lain diluar model regresi yang dianalisis.

\section{SIMPULAN}

Berdasarkan hasil analisis dan pembahasan yang sudah dijelaskan pada bab sebelumnya, dapat diambil kesimpulan sebagai berikut:

a. Return On Assets (ROA), Tingkat Inflasi, Nilai Tukar Rupiah secara bersama-sama berpengaruh positif dan signifikan terhadap harga saham pada perusahaan perbankan yang terdaftar di BEI tahun 2012-2016 dengan $\mathrm{F}_{\text {hitung }}$ $>\mathrm{F}$ tabel yaitu $36.99996>3,06$ dan signifikansi sebesar $0.000000<0,05$

b. Return On Assets (ROA) berpengaruh negatif dan tidak signifikan terhadap harga saham pada perusahaan perbankan yang terdaftar di BEI pada tahun 2012-2016 dengan $t_{\text {hitungsebesar }}$ $0,577606<1,65566$ dan signifikansi sebesar $0,5647>0,05$.

c. Tingkat Inflasi berpengaruh positif dan signifikan terhadap harga saham pada perusahaan perbankan yang terdaftar di BEI pada tahun 2012-2016 dengan $\mathrm{t}_{\text {hitungsebesar }}-14.42283>$ 1,65566 dan signifikansi sebesar $0,0000<0,05$.

d. Nilai Tukar Rupiah tidak berpengaruh negatif tetapi signifikan terhadap harga saham pada perusahaan perbankan yang terdaftar di BEI tahun 2012-2016 dengan $\mathrm{t}_{\text {hitung }}$ sebesar $-12.45095<$ 1,65566 dan signifikansi sebesar $0,0000<0,05$

e. Koefisien determinasi $\left(\mathrm{R}^{2}\right)$ yang dihasilkan dalam penelitian ini sangat kuat yaitu sebesar sebesar $88,57 \%$.

\section{DAFTAR PUSTAKA}

Ghozali. (2013). Metode Riset untuk Ekonomi dan Bisnis: Teori, Konsep, dan Praktik 


\section{Penelitian Bisnis (Dilengkapi Perhitungan Pengolahan Data dengan IBM SPSS 22.0) (Metode Ris). Semarang: Metode Riset untuk Ekonomi dan Bisnis: Teori, Konsep, dan Praktik Penelitian Bisnis (Dilengkapi Perhitungan Pengolahan Data dengan IBM SPSS 22.0).}

Ghozali. (2014). Structural Equation Modeling Metode Alternatif Dengan Partial Least Squares (PLS) (Edisi 4). Semarang: Badan Penerbit Universitas Diponegoro.

Ghozali. (2016). Aplikasi Analisis Multivariete Dengan Program IBM SPSS 23 (Edisi 8). Cetakan ke VIII. Semarang: Badan Penerbit Universitas Diponegoro.

Hery. (2015). Analisis Laporan Keuangan. Yogyakarta: CAPS.dan Valuasi Saham. Jakarta: Salemba Empat.

Kurniawan. (2014). Metode Riset untuk Ekonomi dan Bisnis: Teori, Konsep, dan Praktik Penelitian Bisnis (Dilengkapi Perhitungan Pengolahan Data dengan IBM SPSS 22.0). Bandung: Alfabeta.

Lupiyoadi. (2015). Praktikum Metode Riset Bisnis. Jakarta: Salemba Empat.

Nopirin. (2012). Pengantar Ilmu Ekonomi Mikro Makro. Yogyakarta: BPFE. 